NURSING RESEARCH IN ACTION 


\title{
Nursing Research in Action
}

\section{Developing Basic Skills}

\author{
Second Edition
}

\author{
Philip Burnard \\ Director of Postgraduate Nursing Studies \\ University of Wales College of Medicine \\ Cardiff \\ and \\ Paul Morrison \\ Senior Lecturer \\ University of Wales College of Medicine \\ Cardiff
}




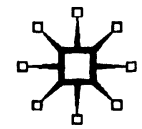

(C) Philip Burnard and Paul Morrison 1990, 1994

All rights reserved. No reproduction, copy or transmission of this publication may be made without written permission.

No paragraph of this publication may be reproduced, copied or transmitted save with written permission or in accordance with the provisions of the Copyright, Designs and Patents Act 1988, or under the terms of any licence permitting limited copying issued by the Copyright Licensing Agency, 90 Tottenham Court Road, London W1T 4LP.

Any person who does any unauthorised act in relation to this publication may be liable to criminal prosecution and civil claims for damages.

The authors have asserted their rights to be identified as the authors of this work in accordance with the Copyright, Designs and Patents Act 1988.

First edition 1990

Reprinted three times

Second edition 1994

Published by

PALGRAVE MACMILLAN

Houndmills, Basingstoke, Hampshire RG21 6XS and

175 Fifth Avenue, New York, N. Y. 10010

Companies and representatives throughout the world

PALGRAVE MACMILLAN is the global academic imprint of the Palgrave Macmillan division of St. Martin's Press, LLC and of Palgrave Macmillan Ltd. Macmillan is a registered trademark in the United States, United Kingdom and other countries. Palgrave is a registered trademark in the European Union and other countries.

ISBN 978-0-333-60876-0 ISBN 978-1-349-13409-0 (eBook)

DOI 10.1007/978-1-349-13409-0

This book is printed on paper suitable for recycling and made from fully managed and sustained forest sources.

A catalogue record for this book is available from the British Library.

Transferred to digital printing 2002 


\section{To Sally, Aaron and Rebecca}

and

for Franziska, Sarah and Maeve 


\section{Acknowledgements}

The authors would like to thank Bunny le Roux, Principal Lecturer, Department of Applied Statistics and Operational Research, Sheffield Hallam University for permission to reproduce the statistical exercise in Chapter 8; and the Science and Engineering Research Council for permission to adapt material from $A n$ Approach to Good Supervisory Practice (1983).

Every effort has been made to trace all the copyright holders, but if any have been inadvertently overlooked the publishers will be pleased to make the necessary arrangement at the first opportunity. 


\section{Contents}

About the authors

vii

Preface

1 An Overview of the Research Process 1

2 Planning Your Research Project 16

3 Searching the Literature 29

4 Approaches to Research Methodology 47

5 Choosing a Research Method 60

6 Methods of Collecting Data 73

7 Other Methods of Collecting Data 95

8 Methods of Analysing Data 114

9 Undertaking the Research Project 135

10 Writing the Research Report 145

Compendium of Useful Information 157

How to quote references in research reports 157

Computer programs $\quad 160$

Literature resources $\quad 162$

Ethical codes $\quad 163$

List of nursing journals $\quad 165$

List of bibliographies, indexes and abstracts 166

Tests, scales and other instruments for data collection $\quad 167$

Useful addresses and sources of information $\quad 169$

Bibliography $\quad 170$

References $\quad 170$

Recommended further reading $\quad 170$

$\begin{array}{ll}\text { Index } & 178\end{array}$ 


\section{About the Authors}

\section{Philip Burnard}

Philip is Director of Postgraduate Nursing Studies at the University of Wales College of Medicine and Honorary Lecturer in Nursing at the Hogeschool Midden Nederland. He has carried out a variety of research projects including ones into experiential learning, AIDS counselling, interpersonal skills and forensic psychiatric nursing. Author of a variety of books about nursing and health care issues, he is a frequent contributor to the nursing press.

\section{Paul Morrison}

Paul is a Senior Lecturer at the University of Wales College of Medicine, where he teaches the psychology component of the Bachelor of Nursing course. He is a chartered psychologist and an Associate Fellow of the British Psychological Society. Author of a number of books, his research interests include the provision of psychological care in health care settings, management of disturbed behaviour in psychiatric care, and assessment of interpersonal communication skills. 


\section{Preface}

Research is a means of understanding, assessing and evaluating what we do as nurses. It can help us to plan for the future. It can be exciting and satisfying. It can also be hard work. If you are just beginning to study research this book will help you to think ahead and to anticipate the stages of the research process. It will also help you to develop certain basic research skills that are common to all research. Whilst research is never a clear-cut and tidy process, one alternative to being overwhelmed by the task and giving up is to develop structure. In this book we develop a structured approach to research.

The book aims to make research into nursing possible for those who are just setting out in the field. It offers a series of achievable exercises in all the phases of the research process. As you do the exercises you will begin to follow the process of how to do research yourself, or to develop an understanding of what other researchers have done. We suggest that after you have finished working through this book, you do a small piece of research yourself. However, we do not suggest that you do it alone. As we noted above, research is often hard work and uses a whole range of skills. It is not something to be rushed into.

It is not our intention that this book should stand alone. It is a book that can be used as a guide alongside other texts on research. It should also be used in conjunction with a tutor and with other nursing colleagues.

We are both nurses and both teach research methods. Driven by the idea that there is no better way to learn to do something than by doing it, we have undertaken a number of research projects both large-scale and small. We have also supervised the research projects of students. In the process we have learned some things about doing research. We have learned, for instance, that there is no one 'right' way to do research. We have also learned that one of the best ways to learn research is to do it. We hope that this book will allow you to sample various aspects of the research process as a means of building up a range of research skills and confidence in evaluating research which you might use. 
The book may be used in a variety of ways:

- It may be used on its own as a learning package. A nurse working through the book on his/her own can do the various exercises and follow up the various approaches through reference to the various books and articles recommended throughout the text. $S($ he) may also do further reading via the extended recommended reading list at the back of the book. The compendium of research resources, also at the back of the book, will be a further aid.

- The book may also be used as part of a student-centred learning programme. Nurse educators are realising, increasingly, that people learn at different speeds and that their learning needs vary. Thus, the book can be tailored to suit the varying needs of the people using it. For some, it will help to work right through the book as an introduction to research methods. For others, it will be more appropriate to select certain chapters relating to specific skills.

- It may be used as a programme of guided reading. The book unfolds logically to cover all the stages of the research process. As it does this, a wide and varied range of references is offered. Readers are given the opportunity to sample different sorts of research. Thus the book can be a rich source of reference for the person who wishes to become familiar with a broad view of the research literature. Examples of research projects are drawn not only from nursing but from the whole range of social sciences. We feel that it is important that nurses sample and explore all sorts of approaches to doing research.

- The book may be used as a resource. Many of the passages can serve as the means by which ideas are sparked off or the next stage of a research project is planned. The references offered throughout the book and in the bibliography will also be useful in gaining new leads and developing thoughts and plans.

- Experiential learning, or learning directly through personal experience, is also a growing trend in nurse education. The book is not only theoretical in nature. It invites the reader to complete a range of exercises to reinforce learning. Thus, used in a group context and with group reflection after the completion of each exercise, the book can be used as an aid to facilitating experiential learning. If the book is used in this way, it is recommended that the following issues are born in mind:

- The tutor or facilitator should appreciate that each student will tend to find different results at the end of each exercise. It is useful if the tutor does not try to force a particular point of view on the group but allows for these differences of perception.

- Plenty of time should be allowed for the completion of the exercises and about an hour should be allowed afterwards for discussion or 'processing' of the activity. 


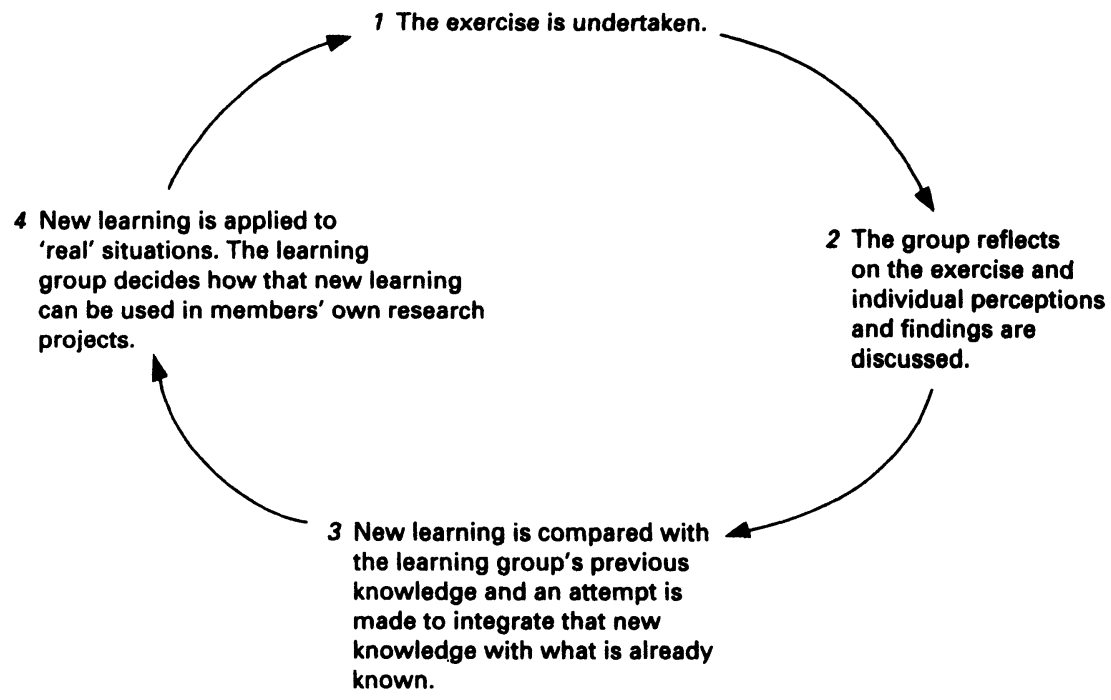

An experiential learning cycle applied to the exercises in this book

- It is helpful if the tutor reads through a particular exercise that is being used and makes sure that all learners have access to the various research reports and other references that are cited in the text. If nurses are to plan and carry out research projects it is essential that they have easy access to a well-stocked library. As we noted earlier, the references quoted in this book are drawn from a wide variety of sources within the social and behavioural sciences. Whilst they are all obtainable via the inter-library loan system, it is clearly more helpful to learners if they are more readily available.

- It is useful if the experiential learning cycle shown above is used in order to make full use of the exercises.

The book offers an exploratory approach to most aspects of the research cycle. Both quantitative and qualitative methods of doing research are addressed as are a variety of ways of collecting and analysing data. The reader is encouraged to draw up a research proposal, identify proposed data collection methods and methods of analysis, and is then directed towards writing up the project. A series of 'information sections' is offered throughout the text to illuminate certain aspects of the topics under discussion. At the end of the book, as we have already noted, there is a compendium containing further information on all sorts of aspects of the research process. Overall, the book should serve as a practical introduction to the business of doing research in nursing. 
We have been unable to find a satisfactory solution to the problem of non-sexist language. Using 'they' as both singular and plural was considered but deemed to be clumsy. In the end, we settled for the nurse as 'she', though we wish to acknowledge that the reader may just as easily read 'he' in its place. The issue of how to write clear and unambiguous non-sexist prose remains a challenge both for the writer generally and for the person who is reporting research.

More than anything else, we hope that the book will make you think about the issues involved in doing research - whether or not you do your own research.

Cardiff, 1994

PHILIP BURNARD

PAUL MORRISON 